\title{
Systemic lupus erythematosus and thyrotoxicosis: a hitherto little recognised association
}

\author{
S RODRIGUE, H LABORDE, AND P M CATOGgIO*
}

From the Rheumatology Section, 6th Chair of Internal Medicine, University Hospital, Buenos Aires: Argentina

SUMMARY Six patients are reported in whom systemic lupus erythematosus (SLE) an $\dot{\delta}_{0}$ thyrotoxicosis coexisted. All had four or more American Rheumatism Association criteria (1982 $\dot{q}_{\mathrm{r}}$ for the diagnosis of SLE and had clinical manifestations and function test results characteristic of hyperthyroidism (except for one who had been thyroidectomised previously). In three patient $\$$ the diagnosis of hyperthyroidism preceded that of SLE, in two patients both diseases began simultaneously, and only in one was the diagnosis of thyrotoxicosis made after that of SLE. It is suggested that hyperthyroidism associated with SLE may be a form of presentation of thyroiditis? This association may pass unnoticed because of the similarity of some clinical manifestations $\vec{\bullet}$

Key words: hyperthyroidism, thyroiditis, Graves' disease, autoimmune diseases.

Coexistence of immune thyroid dysfunction and inflammatory connective tissue disease has been the subject of several reports during the past three decades. ${ }^{1-5}$ Thus Hashimoto's thyroiditis has been described in association with rheumatoid arthritis, ${ }^{6}$ systemic lupus erythematosus (SLE), ${ }^{37-10}$ polymyositis-dermatomyositis, ${ }^{11}$ scleroderma, ${ }^{12} 13$ and Sjögren's syndrome. ${ }^{14}$ In addition, antithyroid antibodies are frequently found in different connective tissue diseases ${ }^{12}$ as well as in other diseases thought to have an immune basis, even in the absence of clinical manifestations of thyroid disease. $^{15}$

Despite the acknowledged autoimmune mechanism in Graves' disease its clinical association with connective tissue disease has not been clearly established. We describe six patients in whom SLE coexisted with clinical and laboratory manifestations of thyrotoxicosis, typical of Graves' disease.

\section{Patients and methods}

Five of 93 patients with SLE followed up by our group since 1980, who showed manifestations of thyrotoxicosis, together with a sixth patient with coexistence of both diseases who had been seen in 1973, were included in the study.

Accepted for publication 20 September 1988.

Correspondence to Dr S Rodrigué, Av. Córdoba 2062, 1 Piso 'B', (1120) Buenos Aires, Argentina.

${ }^{*}$ Deceased.
All patients were women aged 23 to 41 years and had at least four American Rheumatism association criteria (1982) for the diagnosis of SLE. In all six patients antinuclear antibodies were looked for byg indirect immunofluorescence using rat liver as substrate. Antibodies to native DNA were also sough by passive haemagglutination or complement fixa tion, or both. Venereal Disease Research Laborator tests and lupus erythematosus cells were done in alb patients.

Five of the six patients had symptoms and signs of hyperthyroidism: diffuse goitre, weight loss, ocular signs, heat intolerance, loss of strength, and othe? manifestations. A thyroid scan was carried out and ${ }^{131}$ I uptake curves constructed. The sixth patient had. been thyroidectomised at the time of observation and was euthyroid. When possible, antithyroid? antibodies were sought by haemagglutination, and serum concentrations of triiodothyronine and thyr oxine by radioimmunoassay.

\section{Results}

FEATURES OF SLE

Lupus manifestations were varied and of differing severity (Table 1). Two patients died: one, owing top renal failure related to active glomerulonephritis $\frac{?}{\mathrm{D}}$ and the other, with central nervous system involve $\stackrel{0}{2}$ ment. In two patients the disease had a moderate course without overt renal involvement and with of good response to corticosteroid treatment. The two 
Table 1 Features of systemic lupus erythematosus

\begin{tabular}{|c|c|c|c|c|c|c|}
\hline \multirow{2}{*}{$\begin{array}{l}\text { Patient } \\
\text { No }\end{array}$} & \multirow[t]{2}{*}{ Clinical and laboratory findings } & \multicolumn{4}{|c|}{ Serum findings } & \multirow{2}{*}{$\begin{array}{l}1982 \text { ARA } \\
\text { criteria score }\end{array}$} \\
\hline & & $A N A^{*}$ & anti-DNA & $V D R L^{*}$ & $L E^{*}$ cells & \\
\hline 1 & $\begin{array}{l}\text { Rash, photosensibility, arthritis, } \\
\text { leucopenia, nephritis }\end{array}$ & $+\dagger$ & - & - & - & 6 \\
\hline 2 & $\begin{array}{l}\text { Arthritis, pleuritis, pericarditis, } \\
\text { leucopenia }\end{array}$ & $1 / 300$ & + & + & + & 5 \\
\hline 3 & $\begin{array}{l}\text { Oral ulcers, pleuritis, pericarditis, } \\
\text { arthritis, renal and } \mathrm{CNS}^{*} \text { disease }\end{array}$ & $1 / 600$ & + & - & + & 7 \\
\hline 4 & $\begin{array}{l}\text { Arthritis, pleuritis, pericarditis, } \\
\text { nephritis }\end{array}$ & $1 / 400$ & - & - & - & 4 \\
\hline 5 & $\begin{array}{l}\text { Oral ulcers, arthritis, pleuritis, } \\
\text { pericarditis, nephritis, leucopenia }\end{array}$ & $1 / 3200$ & + & + & + & 7 \\
\hline 6 & $\begin{array}{l}\text { Rash, photosensibility, arthritis, } \\
\text { nephritis }\end{array}$ & $1 / 400$ & + & - & + & 6 \\
\hline
\end{tabular}

*ANA=antinuclear antibodies; VDRL=Venereal Disease Research Laboratory test; LE=lupus erythematosus; CNS=central nervous system.

†Titre unknown.

remaining patients, with diffuse proliferative glomerulonephritis, required immunosuppressive treatment. No particular clinical features were common to these patients (Table 1). All had antinuclear antibodies and, in four, anti-DNA antibodies were found.

\section{FEATURES OF THYROTOXICOSIS}

In the five patients in whom a thyroid scan was performed diffuse goitre was confirmed and ${ }^{131} \mathbf{I}$ uptake curves were abnormal (Table 2). Four patients had been adequately controlled with antithyroid drugs (methylmercaptoimidazole) and one patient had recently been given $\beta$ blockers.

ONSET OF INDIVIDUAL DISEASE

In three patients the hyperthyroidism preceded by five years, three years, and six months the onset of lupus manifestations. One of these patients had undergone thyroidectomy with a diagnosis of Graves' disease before admission to hospital. Even though the results of previous studies were not available, typical unilateral exophthalmus was present during the period of our observation until death (owing to central nervous system involvement related to SLE). In two patients both diseases began simultaneously and their coexistence was not diagnosed earlier owing to overlap of clinical manifestations: fever, weight loss, tachycardia, muscle weakness, and tenderness. In only one patient the diagnosis of thyrotoxicosis was made nine years after that of SLE.

\section{Discussion}

The association of diffuse goitre with normal or low thyroid function in SLE is well recognised. ${ }^{34}$ The coexistence of SLE and thyrotoxicosis is less familiar, however. ${ }^{16-19}$ The clinical association between

Table 2 Features of thyroid disorders

\begin{tabular}{|c|c|c|c|c|c|c|c|c|c|c|c|}
\hline \multirow[t]{3}{*}{$\begin{array}{l}\text { Patient } \\
\text { No }\end{array}$} & \multirow{3}{*}{$\begin{array}{l}\text { Clinical } \\
\text { thyrotoxicosis }\end{array}$} & \multirow[t]{3}{*}{ Exophthalmus } & \multirow{3}{*}{$\begin{array}{l}\text { Diffuse } \\
\text { goitre }\end{array}$} & \multirow{3}{*}{$\begin{array}{l}\text { Thyroid } \\
\text { scan* }\end{array}$} & \multicolumn{3}{|c|}{${ }^{131}$ I uptake $(\%) \dagger$} & \multirow{3}{*}{$\begin{array}{l}\text { T3‡ } \\
(\mathrm{nmol} / \mathrm{l})\end{array}$} & \multirow{3}{*}{$\begin{array}{l}T 4 \ddagger \\
(\mathrm{nmol} / \mathrm{l})\end{array}$} & \multirow{2}{*}{\multicolumn{2}{|c|}{$\begin{array}{l}\text { Antithyroid } \\
\text { antibodies }\end{array}$}} \\
\hline & & & & & \multirow[t]{2}{*}{$1 h$} & \multirow[t]{2}{*}{$24 h$} & \multirow[t]{2}{*}{$48 h$} & & & & \\
\hline & & & & & & & & & & $A T \ddagger$ & $A M F \ddagger$ \\
\hline 1 & Yes & Yes & Yes & Yes & 37 & 90 & 93 & $\mathrm{ND} \ddagger$ & ND & $1 / 100$ & $1 / 40$ \\
\hline 2 & Yes & No & Yes & Yes & 14 & 95 & 90 & ND & ND & ND & ND \\
\hline 3 & $\S$ & Yes & $\S$ & $\S$ & - & - & - & ND & ND & ND & ND \\
\hline 4 & Yes & No & Yes & Yes & 35 & 73 & 70 & ND & ND & ND & ND \\
\hline 5 & Yes & No & Yes & Yes & 24 & 66 & 69 & 3.6 & 257 & $1 / 100$ & $1 / 12000$ \\
\hline 6 & Yes & No & Yes & Yes & 14 & 53 & 51 & $11 \cdot 6$ & 257 & $1 / 40$ & $1 / 800$ \\
\hline
\end{tabular}

* Large, diffuse distribution.

†Normal value of ${ }^{131} \mathrm{I}$ uptake is $8 \%$ at one hour, $<35 \%$ at 24 hours, and $<32 \%$ at 48 hours.

$\ddagger \mathrm{T3}=$ triiodothyronine (normal value 1.2-3.4 nmol/1); T4=thyroxine (normal value $51-142 \mathrm{nmol} / \mathrm{f}$ ); AT=antithyroglobulin; AMF=antimicrosomal fraction; $N D=$ not done.

§Previous total thyroidectomy. 
these two disorders has only recently been established. Goh and Wang reported thyroid disorders in 14 out of 319 patients with SLE, nine of whom had clinical evidence of hyperthyroidism consistent with Graves' disease.$^{20}$ In eight of these patients thyroid disease preceded the manifestations of SLE by one to 11 years. Only two of these patients with thyrotoxicosis then developed hypothyroidism, one after total thyroidectomy. Miller et al found thyroid disease in 25 of 332 patients with SLE-a clinical prevalence of $7 \cdot 5 \% .^{21}$ Of these 25,22 were hypothyroid and three were hyperthyroid. They studied 175 of the remaining 307 clinically euthyroid patients with SLE with a functional thyroid test and found that 44 had either subclinical hypothyroidism or biochemical primary hypothyroidism and that five others had hyperthyroxinaemia. These features suggest that clinical and functional thyroid dysfunction in SLE is more common than expected. The association of thyrotoxicosis with other autoimmune diseases has not been reported frequently. Marshall et al reported clinical hyperthyroidism in four out of 42 patients $(10 \%)$ with idiopathic thrombocytopenic purpura, and in two additional patients they found a biochemical 'latent' Graves' disease. ${ }^{19}$ Thomas and Croft described hyperthyroidism in five of 59 patients with giant cell arteritis. ${ }^{22}$ Thyroid disease preceded the onset of arteritis in three cases and, in two, onset was simultaneous.

The association of SLE with thyrotoxicosis was higher among our patients than that reported by other authors. Either ethnic factors or the difficulty of identifying the coexistence of these two disorders owing to their similar clinical manifestations may account for these different prevalences. We did not study our remaining patients with SLE with thyroid function tests, thus we do not know the overall prevalence of functional thyroid disorder in our patients with SLE.

The association of Hashimoto's thyroiditis with different autoimmune diseases is well known, and even though the former may begin clinically with transient hyperactivity, this thyroiditis usually manifests with hypoactivity. It is now accepted that there is a close relation between Graves' disease and Hashimoto's thyroiditis and that both diseases may be considered as different forms of the same process. ${ }^{23} 24$ The fact that longstanding thyrotoxicosis has been seen in patients with thyroid glands, which on microscopy proved to be Hashimoto's thyroiditis, ${ }^{23}$ makes it hard to draw clear cut distinctions between these two thyroid disorders; thus suggesting the term 'Hashi-Graves'. It would not be unreasonable, therefore, to suggest that our patients had SLE and perhaps one form of presentation of Hashimoto's thyroiditis.
On the other hand, drug induced SLE related tow? the use of the antithyroid drug propylthiouracil has been reported. ${ }^{25} 26$ True coexistence of both dis - ? eases might have been erroneously attributed to this? observation. None of our patients had been treated $\frac{\bar{s}}{\bar{n}}$ with propylthiouracil, and only two patients had been given methylmercaptoimidazole before developing SLE; this drug and propylthiouracil arês members of the thionamide class. Association of the -5 former drug with induced SLE has not been clearlyestablished. ${ }^{26}$ One of the two patients given methyl- $\vec{\omega}$ mercaptoimidazole had discontinued antithyroif treatment at least one month before the onset of lupus, and the other patient died owing to renaits failure related to active glomerulonephritis.

The early differential diagnosis between SLE and thyrotoxicosis can be difficult because they share some similar clinical manifestations. Perhaps routine inclusion of clinical and functional thyroid tests in patients with SLE and vice versa woulch reveal a larger number of cases of overlap.

\section{References}

1 Anderson J R, Goudi R B, Gray K G, Buchanan W W Antibody to thyroglobulin in patients with collagen diseases Scott Med J 1961; 6: 449-56.

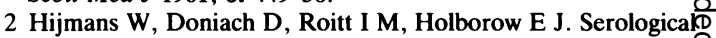
overlap between lupus erythematosus, rheumatoid arthritis and thyroid autoimmune disease. $\mathrm{Br}$ Med J 1961; ii: 909-14.

3 White R G, Bass B H, Williams E. Lymphadenoide goitre and the syndrome of systemic lupus erythematosus. Lancet 1961; i? 368-73.

4 Becker K L, Ferguson R H, McConahey W M. The connective tissue diseases and symptoms associated with Hashimoto's్ thyroiditis. $N$ Engl J Med 1963; 268: 277-80.

5 Mulhern L M, Masi A T, Shulman L E. Hashimoto's disease: P search for associated disorders in 170 clinically detected cases? Lancet 1966; ii: 508-11.

6 Thomas D J B, Young A, Gorsuch A N, Bottazzo G F 윽 Cudworth A G. Evidence for an association between rheumatoid arthritis and autoimmune endocrine disease. Ann Rheumb Dis 1983; 42: 297-300.

7 Weetman A P, Walport M J. The association of autoimmune를 thyroiditis with systemic lupus erythematosus. Br J Rheumatof 1987; 26: 359-61.

8 Larsen $\mathbf{R}$ A, Godal T. Family studies in systemic lupus erythematosus. IX. Thyroid disease and antibodies. J Chronic Dis 1972; 25: 225-33.

9 Garber J J, Worthington J W, Randall R V, Kierland $\mathbf{R} \mathbf{R}$ Lupus erythematosus and Hashimoto's thyroiditis. Postgrack Med J 1969; 46: 100-5.

10 Francis D A. Pure red-cell asplasia: association with systemic్ lupus erythematosus and primary autoimmune hypothyroidism Br Med J 1982; 284: 85

11 Guido J, Andrada J, Capdevielle I F, Mattera R, Bozzolasco C Tiroiditis autoimmune y dermatomiositis. Medicina (B Aires 1964; 24: 340-3.

12 Khal L E, Medsger T A Jr, Klein I. Prospective evaluation of thyroid function in patients with systemic sclerosis (scleroder-
ma). J Rheumatol 1986; 13: 103-7.

13 Gordon M B, Klein I, Dekker A, Rodnan G P, Medsger T A Jr. Thyroid disease in progressive systemic sclerosis: increase 
frequency of glandular fibrosis and hypothyroidism. Ann Intern Med 1981; 95: 431-5.

14 Karsh J, Paulidis N, Weintraub B D, Moutsopoulos H M. Thyroid disease in Sjögren's syndrome. Arthritis Rheum 1980; 23: $1326-9$.

15 Crowe J P, Christensen E, Butler $\mathbf{J}$, et al. Primary biliary cirrhosis: the prevalence of hypothyroidism and its relationship to thyroid antibodies and sicca syndrome. Gastroenterology 1980; 78: 1437-41.

16 Papadopoulus C, Jiji R, Maher E. Lupus erythematosus and hyperthyroidism. Am J Dis Child 1969; 118: 621-5.

17 Cheah J S, Chia B L, Tay H H, Tan B Y. Hyperthryoidism in systemic lupus erythematosus. Med J Aust 1970; 2: 1029-30.

18 Oren M E, Cohen M S. Immune thrombocytopenia, red cell aplasia, lupus, and hyperthyroidism. South Med J 1978; 71: 1577-8.

19 Marshall J S, Weisberger A S, Levy R P, Breckenridge R T. Coexistent idiopathic thrombocytopenic purpura and hyperthyroidism. Ann Intern Med 1967; 67: 411-4.
20 Goh K L. Wang F. Thyroid disorders in systemic lupus erythematosus. Ann Rheum Dis 1986; 45: 579-83.

21 Miller F W, Moore G F, Weintraub B D, Steinberg A D. Prevalence of thyroid disease and abnormal thyroid function test results in patients with systemic lupus erythematosus. Arthritis Rheum 1987; 30: 1124-31.

22 Thomas R D, Croft D N. Thyrotoxicosis and giant-cell arteritis. Br Med J 1974; ii: 408-9.

23 Fatourechi V, McConahey W, Woolner L B. Hyperthyroidism associated with histologic Hashimoto's thyroiditis. Mayo Clin Proc 1971; 46: 682-9.

24 Tamai $\mathrm{H}$, Nakagawa $\mathrm{T}$, Ohsako $\mathrm{N}$, et al. Changes in thyroid functions in patients with euthyroid Graves' disease. J Clin Endocrinol Metab 1980; 50: 108-12.

25 Librik L, Sussman L, Bejar R, Clayton G W. Thyrotoxicosis and collagen-like disease in three sisters of American Indian extraction. $J$ Pediatr 1970; 76: 64-8.

26 Amrhein J A, Kenny F M, Ross D. Granulocytopenia, lupuslike syndrome, and other complications of propylthiouracil therapy. J Pediatr 1970; 76: 54-63. 